practice "for the peoples of the world" and instructed the W.M.A. Council fully to investigate this matter in South Africa and "any other parts of the world considered necessary." Despite the alarmist letter from Dr. G. W. Gale (29 September, p. 692) no attempt was made to expel South Africa from the W.M.A. as had been done by the Commonwealth Medical Association in 1970. Ghana stressed that her resolution was not intended to indict but to help the Medical Association of South Africa in its difficult task. Ghana pointed out that there were few African members in the W.M.A. and that the W.M.A.'s attitude to colour discrimination would probably affect potential Black membership. One might have hoped that these warning notes would have reminded the Assembly that it was handling an issue whose implications stretched far beyond South Africa's boundaries.

I would like to draw your readers' attention to certain important facts, mostly omitted from the B.M.F. report.

(1) The chairman of the Resolutions Committee (Dr. J. K. Bremer, South Africa) resigned to avoid having to preside over the discussion of Ghana's resolution.

(2) South Africa, backed by Britain, West Germany, and others, tried to block the acceptance of the newly constituted Resolution Committee's raport. The long procedural wrangle was ended only by a presidential decision that Ghana's resolution should be accepted for debate.

(3) The Munich Assembly showed inconsistency in both the type of ethical problem it was prepared to handle and its policy on naming the country involved. It dealt with issues such as the amputation of hands for theft and torture, but not with a wellknown and specific case of colour discrimination. It did not hesitate to name Libya in the former case, but refused to mention South Africa in the latter. In their embarrassed side-stepping, those who felt that "rightly in the final resolution the reference was made world wide" might be accused of indulging in "polite window-dressing" (Ghana's words to the Assembly). Ghana's resolution clearly included the worldwide situation.

(4) Before the final vote on Australia's and West Germany's amendments the chairman of the Council assured the Assembly that a full investigation into colour dis crimination in South African medicine would go ahead even if the amendments were carried.

Those delegates within the W.M.A. who were intent first on blocking this vita resolution and then on watering it downand this includes the B.M.A. delegatesshould fully realize the implications of their actions. It is significant that Ghana officially recorded that her association would have nothing to do with the amendments proposed. It is very relevant to the W.M.A.'s future that when the Assembly succeeded in carrying these amendments all the Black countries, as well as Turkey, Uruguay, and Venezuela, voted against Ghana's amended resolution. The interesting contrast with the votes of South Africa and the entire European block did not pass unnoticed.

As I left Munich those opening remarks of Dr. D. P. Stevenson- "We must open the doors wider" and "The 1977 Assembly will be held in Africa"-took on another meaning. In calling for an enlarged membership, had the W.M.A. Assembly forgotten that there is such a body as the Organization of African Unity? Had it also forgotten the close ties between the so-called "third world" and eastern-block countries? It had clearly forgotten (or maybe never realized?) the farreaching implications of the colour/ethnic group issue in this vast tract of world medicine which is, alas, now likely to remain unrepresented in the so-called "World" Medical Association.

Perhaps there is still one last chance for the W.M.A. Though many of us are disillusioned in the W.M.A.'s performance, no one should doubt the skill and vast international experience of its new SecretaryGeneral, Sir William Refshauge. Those of us who still passionately believe in the need for a truly representative international medical body now look to him to do everything possible to heal the wounds inflicted by the Munich Assembly.-I am, etc.,

Guy's Hospital,

SuE Dowling

London S.E.1

SIR,-More remarkable than the proposed "naming" of South Africa by a group of member associations of the World Medical Association which that body at Munich, in its wisdom, did not agree to, was the fact that the nine member associations who, by voting against the amended motion, ipso facto actually voted for "discrimination on grounds of religion, race, colour, or politics of any form in the training of medical practitioners and in the practice of medicine and in the provision of health services to the peoples of the world."

Perhaps it was your editorial caution which deterred you from publishing the names of the nine member associations (3 November, p. 245, and Supplement, p. 26). For us to know who they are is of considerable significance in view of the very nature of the resolution.-I am, etc.,

Cape of Good Hope,

THEODORE JAMES

South Africa

\section{Treatment of Hypothyroidism}

SIR,-The letter from Dr. D. C. Evered and Professor R. Hall (17 November, p. 425) throws some light on the statement in their paper (21 July, p. 131) that "the raised level of serum triglyceride concentration is unexplained and has not been reported pre viously." "Raised" refers to a change after treatment in four patients and not to the difference in mean value between their controls $(103 \mathrm{mg} / 100 \mathrm{ml})$ and one of their treated groups $(150 \mathrm{mg} / 100 \mathrm{ml})$. The four patients to whom they refer had serum triglyceride levels between 110 and 140 $\mathrm{mg} / 100 \mathrm{ml}$, which are not raised above normal, and one cannot tell without some statistical information whether they are different from the pre-treatment values. If there is no significant difference, they have nothing to explain.

In the same issue of the B.M.f. there are interesting letters from Drs. Mary J. E. Van Der Vis-Melsen and Jan D. Wiener (p. 419) and from Drs. H. Hedstrand and L. Wide (p. 420) on the possible influence of thyrotrophin (TSH) on blood lipids. Drs. Van
Der Vis-Melsen and Wiener suggest that the observed increase in the serum cholesterol is a direct effect of thyrotrophin-releasing hormone (TRH) or of TSH. There is evidence that TSH itself, rather than TRH, causes serum triglyceride levels to rise. ${ }^{1}-1$ am, etc.,

Charing Cross Hospital,

P. B. S. FOWLER

London W. 6

Fowler, P. B. S., British Medical fournal, 1972, $1,247$.

\section{Measles}

SIR,-We were interested to read Dr. S. R Saxena's letter (22 September, p. 632) in response to your leading article (28 July, p. 187) on the pathogenesis of measles. He comments that "despite the advent of measles vaccine this disease remains a challenging problem for the treating doctor, especially in India." A study comparing the mortality and morbidity of measles during 1936 and 1972 was recently undertaken in Glasgow. Dr. Saxena's observations of measles morbidity in Hyderbad, India, during 1964-6 were similar to those made in Glasgow (with similar population size) during 1936.

Mortality due to measles in Scotland started to show a steady fall in the period $1926-40$ (from 19.1 per 100,000 population in 1926 to 3.4 per 100,000 in 1940). This was foilowed by a dramatic improvement $(0.1$ per 100,000 in 1971). It is likely that the availability of antibiotics after 1940, the establishment of the National Health Service in 1948 , and the advent of measles vaccine in 1954, with its subsequent general use in Britain by 1968 , may have contributed to the overall decrease in the mortality and morbidity of measles. The decreasing trend of mortality before 1940 may be attributed largely to the alteration in the living style of British society, with improvement of sanitary conditions, better housing, and increasing awareness of health and disease. The belief of the British public in "nuclear family structure" and the voluntary practice of family planning methods have resulted in a gradual decrease in the birth rate over the years. This important factor may have also contributed to the current decrease in the incidence of measles to some extent by introducing fewer susceptible persons into the community.

The isolated reports of mortality and morbidity due to measles from selected centres $^{2}$ (mostly from urban teaching hospitals) in India are often misleading. Only $20 \%$ of the population of India live in urban areas. A section of this population live up to the maxim of "where the babies are money ain't." These people, owing to their ignorance and poverty, go to the hospitals only when they are desperdtely ill. Ironically (to the epidemiologist) these are the only statistics available. The remaining $80 \%$ of the population live in rural areas, where the villages are small and isolated. Limited studies of measles in rural India $^{3}$ have shown that measles is not so severe a problem as in the urban areas. In support of this, mathematical models 4 have shown that the critical population size required for a measles epidemic to occur is 250,000 . Hence measles may exist mainly as an endemic disease in the rural areas.

The pathogenesis of the severity of 
measles, as of undernutrition in India, is more likely to be at the "grass roots." Seventy per cent. of the Indian population are illiterate and the extended family system is practised in addition to the high birth rate. Ignorant and indiscriminate use of indigenous medicines, strong religious convictions, ${ }^{5}$ and a very poor understanding of the concept of health and disease are likely to be of fundamental importance. Unfortunately these are adding to the avoidable mortality and disabling morbidity due to measles.

Mass immunization against measles in Britain after 1968 disrupted the biennial periodicity of epidemics. This beneficial effect was not sustained for long. In the early part of 1973 a large number of measles cases were again notified. ${ }^{6}$ Predictions of the eradication of measles by mass immunization campaigns were disappointed in the U.S.A. ${ }^{7}$ The live measles vaccines have proved to be safe for mass immunization, but sufficient time has not elapsed to establish whether prolonged immunity is conferred by the vaccine.

Thus before an enthusiastic approach is shown towards measles immunization as a "panacea," it would be prudent to do a cost benefit analysis of this expensive vaccine (£0.50 per dose). For the successful eradication or control of measles a continuous and constant high level of immunity is required in the community. ${ }^{8}$ The undelineable but invaluable health education measures, improvement in sanitary conditions, and removal of stringent religious convictions and dogmas involving health and disease may prove more beneficial in a country such as India. It is known that prophylaxis against measles was practised in ancient India. ${ }^{9}$ Though the ancient practices have lost their meaning during the course of time, they may still be good for the health of the people. If measles in India is a challenging problem owing to human behavioural factors, a vigorous primary preventive approach supported by sound therapeutic measures is more likely to be rewarding.-We are, etc.,

T. A. REDDY

School Health Service

D. REID

Communicable Diseases (Scotland) Unit,

Ruchill Hospital,

Glasgow

1 Reddy, T. A., An Epidemiological Study of Measles. Dissertation submitted to Glasgow
University for the Diploma in Public Health, 1973.

2 Ghosh, S., and Dhatt, P. S., Indian fournal of Child Health, 1961, 10, 111.

Shah, U., Banerii, K. L., Nanavati, A. N. D. and Mehta, N. A., Bulletin of

Organizan S., fourmal of the Royal Statistical Bartlett, M. S., fourmal of the
Society, Series $A, 1957,120,48$.

Society', Series $A$, 1957, 120, 48.
Pereira, S. M., and Benjamin, V., Tropical and Geographical Medicine, 1972, 24, 124.

6 Registrar General's Quarterly Return for England and Wales, 1st Quarter 1973. London, H.M.S.O., 1973 .

7 Conrad, J. L., Wallace, R., and Witte, J. J., American fournal of Public Health, 1971, 61, 2304

8 Sutherland, I., and Fayers, P. M., British Medical

9 Gupta, S. C., Social Science and Medicine, 1970, Gupta,

\section{Think again on Salmon}

SIR,-I unfortunately did not see your leading article (27 October, p. 186) regarding the Salmon structure in hospitals, but have read with interest some of the correspondence provoked thereby. I write as a nurse who feels, like many others, extremely dissatisfied with the present situation, and this I stated in a Personal View in 1971 (7 August, p. 367)

I was very happy as a departmental ward sister. However, at the age of 32 years it was intimated to me that I was far too senior to remain in the wards. I therefore decided that administration was not something I wished to do, and became a tutor instead, simply becasue I was put under pressure. I now find myself employed in a job I do not particularly enjoy and from which I derive no satisfaction. Furthermore, I feel extremely bitter, and this I am afraid is due to the attitude of my medical colleagues when this report was published. I warned the consultants with whom I then worked of the situation which would inevitably arise, and they refused to listen and accused me of overreacting. These same people are now, of course, as worried as everyone else.

I therefore feel that part of the blame must be attributed to the medical profession. If they had supported us when we needed it they would still have their ward sisters. Those of us who have been evicted would be much happier and-who knows?-the patients might even receive adequate care. I am, etc.,

London S.E.1

PAMEla M. JefFERIES

Government, cannot be put into practice as it falls within present pay and price restrictions. It is with some concern, therefore, that I read in your leading article "Phase 3 and Beyond" (17 November, p. 374) that practice expenses for G.P.s are beyond such Government restriction.

There seems to be good reason for the present lack of popularity of the consultant specialty. -I am, etc.,

University Hospital of Wales,

T. S. BROWN Cardiff

${ }^{*}{ }^{*}$ The Secretary writes: The pay of N.H.S hospital doctors as salaried employees is taxed under schedule $E$, and expenses for such things as moving house are classed as allowances. These fall within the Pay Code. General practitioners, however, are independent contractors and as such are taxed under schedule $D$. They are responsible for the overall cost of running their practices, and expenses incurred in doing this are allowable against tax and are excluded from the Pay Code's restrictions. The N.H.S. reimburses practice expenses in part directly and in part on the basis of "averagain" an Inland Revenue sample of general practitioner tax returns.-ED., B.M.f.

\section{Independence of Review Body}

\section{Salaries in the Health Service}

SIR,-Comments in the press suggest that lay administrative staff of the National Health Service have taken the opportunity afforded by the reorganization of the service to negotiate new salary scales. So far, there are no indications that equal advantage of this reorganization is being taken on behalf of the medical profession. Indeed, it would seem that it is not. If it were, there would be no need for any discussions with $\mathrm{Si}$ Keith Joseph about Phase 3 of the Government's counter-inflation policy (Supplement, 17 November, p. 44). This is a pity, as it would appear that the lay administrative staff have obtained a salary for chief executive officers of area health boards much in excess of that of consultants or of the average income of the general practitioner, as laid down by the Review Body.

Such a state of affairs could hardly be tolerable for long to the medical profession or be conducive to an efficient Health Service. It is to be hoped that in the shor time remaining before the new Health Service comes into being strenuous attempts will be made to produce terms and conditions of service for fully trained medica practitioners which are at least as good as those which have been obtained by lay administrators.-I am, etc.,

Wolverhampton

W. FOWLER

\section{Phase 3 and Beyond}

SIR,-The maxim "united we stand, divided we fall" seems to have been overlooked by the B.M.A. and the Halsbury Review Body.

I was recently informed by one of the B.M.A. office staff that the proposed increase in removal expenses for hospital doctors, which had been accepted in principle by the
SIR,-The letter from Dr. D. F. Hopkins (24 November, p. 494) may be the product of an innocent mind, but it is at least clear, concise, and to the point. It expresses admirably sentiments held by myself and many other doctors to whom I have spoken.

I hope that our leaders will see fit to adopt Dr. Hopkins's admirable suggestion.I am, etc.,

Peterhead, Aberdeenshire

GEORGE I. LUMSDEN

\section{Points from Letters}

\section{Professional Charges}

Dr. D. V. Bateman (Matching, Essex) writes: The last eight words in Dr. J. R. Egerton's second letter (27 October, p. 237) read ". . .train more doctors and then everyone would benefit." (my italics). I wonder; would we ? I have long held and expressed the view that in our biennial bargaining sessions with the Review Body the strongest card in our hand is our relative scarcity. If ever there were enough doctors could we expect to receive even the modest increases in pay we have hitherto been granted ?. . .At least, at present, we can choose where we work and in what specialty. In a situation of too many (or even enough) doctors our nearmonopoly employer could start to think of directing us. .

\section{Selective Treatment of Spina Bifida Cystica}

Dr. R. J. A. Nicol (West Wickham, Kent) writes: In the paper by Dr. J. Lorber (27 October, p. 201) much was made of the disabilities met in children operated upon for this disorder, but nowhere was mention made of emotional disorders and maior insecurity associated with the effects of the malady on the parents. Associated with spina bifida cystica is an unpalatably high incidence of broken marriages and broken homes. We shall all hope that Dr. Lorber's efforts will mean fewer broken homes and broken marriages, and an absence of emotional disorders in the children selected for oprration. 